\title{
DEVELOPMENT OF COMPOSITE MATERIAL FROM TIRE SCRAPES AND LATEX FOR APPLICATION IN THERMAL INSULATION
}

\author{
E. T. L. Cöuras Ford ${ }^{\mathrm{a}, \mathrm{b}}$, \\ J. U. L. Mendes ${ }^{a}$, \\ R. M. Nascimento ${ }^{a}$, \\ C. M. C. Pereira ${ }^{b}$, \\ and A. T. Marques ${ }^{b}$ \\ ${ }^{a}$ Universidade Federal do Rio Grande do Norte \\ Pós-Graduação em Engenharia Mecânica \\ Centro Tecnologia \\ Av. Senador Salgado Filho \\ Campus Universitário, $\mathrm{S} / \mathrm{N}$ \\ CEP. 59072-970, Natal, RN, Brasil \\ elmocouras@hotmail.com \\ ${ }^{\mathrm{b}}$ Universidade do Porto \\ Faculdade de Engenharia - FEUP \\ Instituto de Eng. Mecânica e Gestão Industrial \\ Rua Dr. Roberto Frias, Porto, Portugal
} ABSTRACT

Given the unquestionable need of environmental preservation of discarded industrial residues, the scrape of tires, have been seen as a salutary alternative for addictive in concrete, asphalt production and of other composites materials. In this work, grew a composite the base of scrape of tire as reinforcement and latex as matrix, to be used as insulating thermal in "cold" systems $\left(0^{\circ} \mathrm{C}\right)$. Analyzed the acting of the material was what plays the thermal conservation when submitted the flow of heat. Verified the temperature profiles in the internal surfaces and it expresses of the composite as well as the temperature gradient in the same. As consequence, in function of the answers of the system, conclusions were reached.

Keywords: Cold system, Latex, flow of heat.

\section{INTRODUCTION}

There is a world tendency in looking for alternatives for the traditional materials in all the sections of the economy. In this context, it has been increasing the studies addressed to the rational use of the natural resources and the use of residues spilled in the nature.

Being like this, the recycle that it has been a lot stimulated. Now, in the market, several products that are produced with recycled materials already exist: paper, packing's of aluminum and other metals. Santos (2005), affirms that in spite of this progress, the accelerated development of the society takes everyday, to the environment, a great number of materials pollute the vital elements to the human being survival, such as: soil, air and water. Several residues have been studied for the application in mortars and isolation materials. They are many materials that can be used as insulation; the choice of the appropriate material to a certain process of transfer of heat is made of mechanical property analyses, physics and thermal.

As a material insulating ideal, the comparison among the available options doesn't exist it makes possible the choice of that that best satisfies to the fundamental beginning of the engineering: relationship cost $\mathrm{x}$ benefit. Besides, should be considered environmental parameter and of safety.

Now the great majority of the applications of thermal isolation in systems domestic, commercial and industries in the drop strip and average temperature (up to $180^{\circ} \mathrm{C}$ ), it is made being used aggressive materials to the nature such a mainly as: glass wool, rock wool, polystyrene, EPS among others. Such materials, in spite of the effectiveness in the retention of the flow of thermal energy, possess a considerable cost and when discarded they are long years for they be absorbed by the nature. Trying to adapt to a world politics concerning the preservation of the environment, it was made a study with the intention of developing material composite reinforced with you scrape of tire, residue that is characterized for they have low cost, besides low density when compared to conventional materials.

In that way, to present research it was motivated by the promising economical advantages and you adapt offered by the use of tire residue, tends as objective the development of a composite to be used as insulating thermal to the base of it scrapes of tire and latex for application in hot surfaces $\left(200^{\circ} \mathrm{C}\right)$. 
For this, they were used them you scrape of tire as reinforcement of the composite. Abundant material in every country and with little use, and that has as characteristic principal: lightness, flexibility and low cost. As head office the latex was used. Material originating from of the "Hevea brasilliensis" whose production in Brazil is of the order of 90,000 ton/year, and that has as characteristic principal the little humidity absorption, high elasticity and low cost.

\section{THEORY}

- Residues of tires

With the development of the automobile industry in the century $\mathrm{xx}$, there was also an increment in the generation of residues and byproducts, turning important the regulation of the destination of those materials. The cost of garbage deposition has been increasing, so much for the generated volume, as for the new demands of environmental stamp (Grippi, 2001). The need of creation of techniques exists capable to reuse such materials.

In a general way, the transports are vital for the development and the economical and social wellbeing, however, your high noxious effect is recognized in environmental level. Among the several ones modal existent, it is the road that produces a larger impact in the several components of the atmosphere. The principal caused negative effects are the pollution of the air, for the emission of gases and resulting particles of the combustion and the pollution of the soils for residues of oils, tires and scraps.

Among the components of the section road the tire possesses fundamental and unquestionable paper in the people's daily life, so much in the passengers transport as in the transport of loads. That paper becomes still more important in the countries in development, where the transport of goods is made in your great majority by trucks.

However, the consumption of tires reached expressive numbers. The amount of produced tires every year in the world surpasses 2 million tons in Europe and North America, in Japan that production passes of 1 million tons. The China presents a problem in wide scale, because 80 million scraps of tires were produced and studies show that in 2011 the country will have 200 million abandoned tires (Cao, 2007).

In the world the problem of the inadequate discard of tires in the environment is being a great concern of the society in what refers to the administration of solid residues (Bovea and Galardo, 2006). In Brazil, there are 900 million discarded tires approximately and disposed at inadequate places (Larsen et al, 2006).
The tires when useless they cart a series of problems: they are of slow degradation, perceptible and voluminous, needing appropriate conditions of storage and deposition. According to the classification of residues effective in Brazil (ABNT/NBR 10004), the tire is considered residue class III (inert residue). The placement of tires without use in embankments sanitarium has not been showing if a good solution, once the material is practically incompressible and of slow degradation (approximately 500 years), when compared to the residues to which the embankments are destined.

In Brazil, there is not any verification on the part of the federal government, on the forms of final deposition of the used tires, as well as there is not rising of the deposits of abandoned tires in every country. Some estimates indicate that 35 million carcasses of tires are generated annually (Fiori, 2009).

Still in agreement with Fiori (2009), in the united states they are generated more than 1 tires/person/year; Bertollo (2008) it esteems that in the state of São Paulo 0,46 tires/person/year and in Brazil 0,26 tires/person/year.

It's also unacceptable, under the sanitary point of view, that carcasses of tires are discarded to open skyl once it is focus of proliferation of insects and rodents. That problem can still be accentuated at places where diseases exist transmitted by those you encourage, as: primness and fever yellows. According to data of ministry of health in 2008 (MS, 2008) more than $20 \%$ of the registered cases of "dengue" in the country they are caused by insect that are born in accumulated waters in old tires.

\section{- The Latex}

Some vegetables produce latex, which flow of cuts as resin. Cells called special "latíciferes" produce latex. The alkaline latex was coagulated to form a matrix starting from which the balls and other goods were made. During the first millennium, eraser balls were used by the Mayan. Those "toys" had been made starting from the latex originating from of one it hoists native of Central and South America's. The ashes of the bonfires, that they were used to heat up, might have been the black acquaintance's "black of smoke" first contribution, that from that time went the responsible to give larger resistance to the rubber goods (Leber, 2001).

All the latex is emulsions, in other words, aqueous suspensions of insoluble materials among them can be included: resins, felonies, proteins, sugars and carbon hydro's. Nor all the latex is elastic; those with elasticity contain carbon hydro's of long chains. Rubber is a coagulated of elastic latex. Vegetables that produce latex elastic band are thoroughly "new tropics". The commercial natural rubber is produced of the latex of the "Hevea 
Brasiliensis", originally collected of wild trees in South America.

As the rubber was recognized as a material that presented interesting physical properties, the researchers of the beginning of 1700 began to study the behavior of natural rubber when mixed in solvents, with the objective of developing some material that goes water balloon that possessed elasticity for production of balloons to hot air.

The modernization of the industry of polymeric began with the development of the rubber in Europe. Your first appearance in the commercial scenery dates of the century XVI, when French began to discover the advantages and applications of that material. In 1820, Thomas Hancok began the obtaining of products of the rubber and in 1837 it patented an equipment for mixture and rubber mastication (Hancok, 2008).

M. Faraday in 1826 was the first to analyze the chemical structure of the material and it was the first to postulate that was treated of a material constituted exclusively of carbon and hydrogen. The heating took the one reside and one distilled of carbon hydro's with one formulates empiric equal $\mathrm{C}_{5} \mathrm{H}_{8}$.

The volatile fraction was characterized in England in 1860 as tends an ebullition point among $37-38^{\circ} \mathrm{C}$, and it was called isoprene. Your structure was determined by W. Tilden, when studied the volatile fraction separately. And it concluded that that fraction was the responsible for your elasticity.

The fundamental discovery for the development of the rubber happened in 1839 for Nathaniel Hayward and Charles Goodyear, in the United States and Thomas Hancok in England, in independent works. Although the merit has been granted to Goodyear, both obtained similar plenty results. They heated up the natural rubber with sulfur and white lead obtaining this way a material with superior properties to the one of the natural rubber. The properties of the rubber vulcanized, name of the cure process then developed, it constituted, and it still constitutes, a model so that one can have idea of your properties elastic including among other, the possibility of great prolongations, high hardness, resistance to the stretching and fast retraction.

Brazil was already the largest producer and exporter of the natural rubber of latex of the world, same because the "seringueira" is original of the Amazonian. Time that the North area of Brazil tried a moment of great prosperity, becoming the economical area of the country in the beginning of the century XX. That position was occupied until the decade of 50. Economical problems and curses in the area impeded the maintainable development of the activity.

Today, most of the world production of $6,850,000$ ton/year of natural rubber comes from the Asian Southeast, with a total of 5,126,700 ton/year. Brazil answers for a production of 90,000 ton/year of a total of 134,000 ton/year of Latin America. In
Brazil the cost is of US\$ 0.98/ $\mathrm{kg}$ (EMBRAPA, 2011). Nowadays, the natural rubber is produced at the country through cultivation of plants of high productivity, selected and also adapted the areas Southeast and Center-west of the country.

\section{- Composite}

A composite consists of the combination of two or more materials with different individual characteristics. One is the phase continuous or main and the other is the phase it disperses, being obtained, starting from that combination, a new material with properties different from the individual phases (Callister, 1997).

The composites represent a case of matter importance inside of the group of the mixtures polymeric, where, in a general way, it can be said that constitute a class of heterogeneous materials. Given your vast application, special attention has been given all over the world by researchers, in the sense of to get better and to create new way materials the one that a range every time larger of that important material is had and with this, to increase the consumption perspectives (Mano, 2000).

The principal elements that are part of the structure of the composites: reinforcement - gives larger responsibility in the load support. Matrix responsible for the form of the piece and some properties physical-chemistry polymeric. The reinforcement can be of nature organic or inorganic (metallic or ceramic), in way regular or irregular. In general the same is available in the form of fibers (fabric or no-fabric) or particles (spherical, plane...). The matrix is almost always a polymeric one organic soft or hard, thermoplastic or thermo fix, could also be metallic or ceramic. The paper of the matrix in the transfer of the applied load to the reinforcement is of highest importance, since the same feels through the interface reinforcement /matrix.

\section{EXPERIMENTS}

Aiming at the production of the composite for development of the research in subject, it was used scrape of tire originating from of recycled residue to serve as reinforcement and the natural rubber (latex) to serve as matrix polymeric.

\section{- Reinforcement}

As reinforcement, was used scrapes of tire (Fig. 1), obtained through the process of tire recycled, supplied by tire companies, located in the city of Natal - Brazil. 


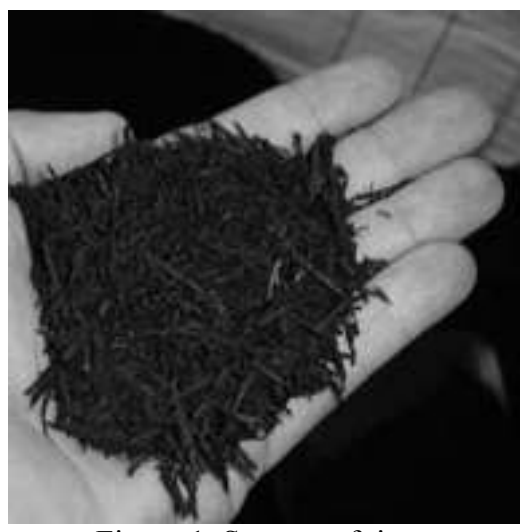

Figure 1. Scrapes of tires.

- Matrix

As matrix, was used natural rubber (latex), originating from the Amazonian - Brazil. Where was extracted of Hevea Brasiliensis (Fig. 2).

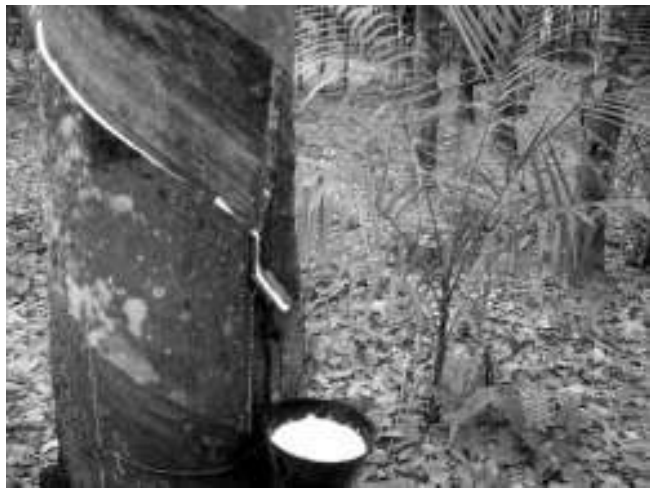

Figure 2. Extraction of natural rubber.

\section{- Composite}

For production of the composite the tire residue was used scrapes with aleatory distribution, interfering in this residue, the natural rubber (latex) as matrix polymeric. Composites were manufactured in the proportions $1: 2(33: 67 \%) ; 1: 1(50: 50 \%)$ and $2: 1(67: 33 \%)$ (scrapes of tire : latex) (Table 1), kindred that roots possible to identify the advantages and disadvantages of the increase or decrease of the proportion of the reinforcement or matrix.

Table 1. Composition of the composites.

\begin{tabular}{|c|c|}
\hline Composites & Reinforcement/Matrix \\
\hline Composite 2:1 & $67: 33 \%$ \\
\hline Composite $1: 1$ & $50: 50 \%$ \\
\hline Composite $1: 2$ & $33: 67 \%$ \\
\hline
\end{tabular}

- Production of the composite blankets

For the production of the composite blankets, the scrape of tire and the latex they were heavy in the wanted proportions, mixed until the formation of a pasty mass and placed in forms of steel of geometry rectangular $25 \mathrm{~cm}$ of length, $12 \mathrm{~cm}$ of width and $1 \mathrm{~cm}$ of thickness. After approximately 24 hours of cure the blankets were removed in the ways and they were ready for used, as can be observed in the figure 3 .

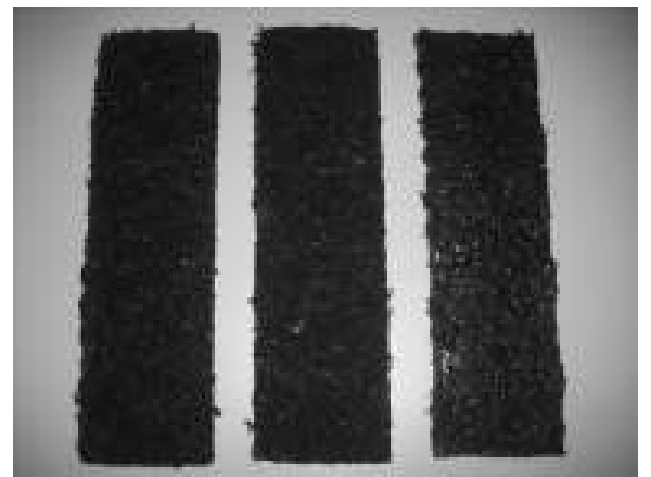

Figure 3. Composites 1:2;1:1 and 2:1 (scrape of tire latex) respectively.

- Resistance to the flow of heat in cold systems

The behavior of the thermal insulating composite in cold systems was analyzed in a wind tunnel with $4.5 \mathrm{~m}$ of length, rehearsal section with dimensions of $0.50 \mathrm{~m} \times 0.50 \mathrm{~m}$, with $0.25 \mathrm{~m} 2$ area.

The experiments were led being placed inside the tunnel capsules of aluminum with external diameter of $25.2 \mathrm{~mm}$, internal diameter of $25 \mathrm{~mm}$ and height of $55 \mathrm{~mm}$, with internal volume of $26.99 \mathrm{~cm} 3$, where inside which a block of ice existed whose temperature was monitored by thermocouples type $\mathrm{T}$ inserted through a hole in the capsule. The capsules of aluminum were submitted the a flow of air with speed of $7.5 \mathrm{~m} / \mathrm{s}$ measured through an anemometer, and a capsule was without isolation (pattern); another was involved with a layer of $5 \mathrm{~mm}$ of the composite in the proportion 1:2; other with composite $1: 1$ and other with composite 2:1 (scrapes of tires - latex) respectively. Figures 4 and 5 show details of the used system.

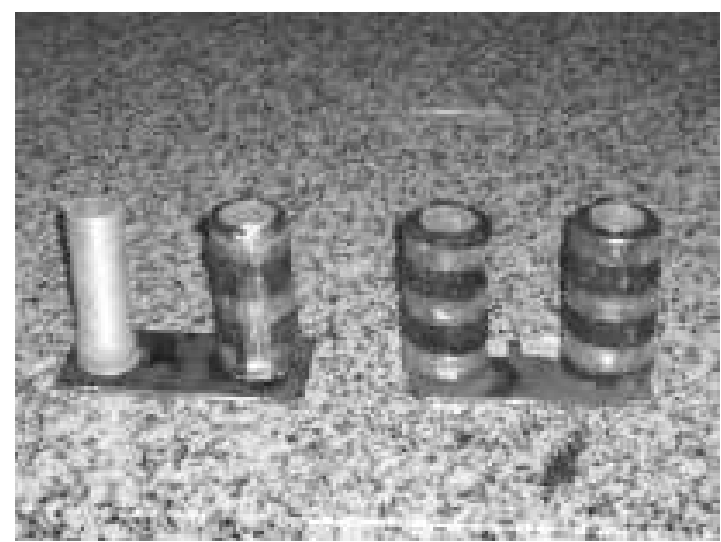

Figure 4. Capsule pattern and with composite $2: 1 ; 1: 1$ and $1: 2$ respectively. 


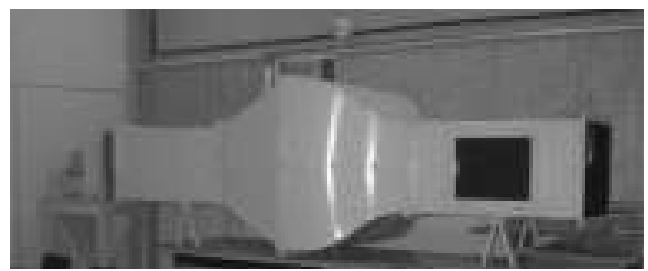

Figure 5. Wind tunnel used in the experiment.

The experiments were divided in four stages, being used at the same time in each stage a capsule without isolation and another isolated, as specified to proceed:

Experiment 1 - capsule pattern / capsule with composite 2:1;

Experiment 2 - capsule pattern / capsule with composite 1:1

Experiment 3 - capsule pattern / capsule with composite $1: 2$

Experiment 4 - capsule pattern / caps. composite 2:1 / caps. composite $1: 1$ and caps composite $2: 1$;

The capsules totally filled out with ice they were placed in the section of tests of the wind tunnel, side by side; the capsule pattern (without coating) and the capsule covered with the material to be analyzed (composite). soon after, called the source of continuous current feeding of the fan of the wind tunnel, which induced a draught with medium speed of $7.5 \mathrm{~m} / \mathrm{s}$, measure through an anemometer, marks ALFA Electronics, model AM - 4201, the variation of the temperature of the blocks of ice to the total coalition was measured and, comparative analyses were made.

\section{RESULTS AND DISCUSSION}

Concerning the temperature variations in the composite $2: 1 ; 1: 1$ and $1: 2$ in cold systems, it is known that the capsules were submitted the flow of air with constant speed of $7.5 \mathrm{~m} / \mathrm{s}$, certain through the anemometer. In Figure 6 the temperature variations can be observed in the capsules pattern and with composite $2: 1$ in function of the time, obtained through the thermocouples.

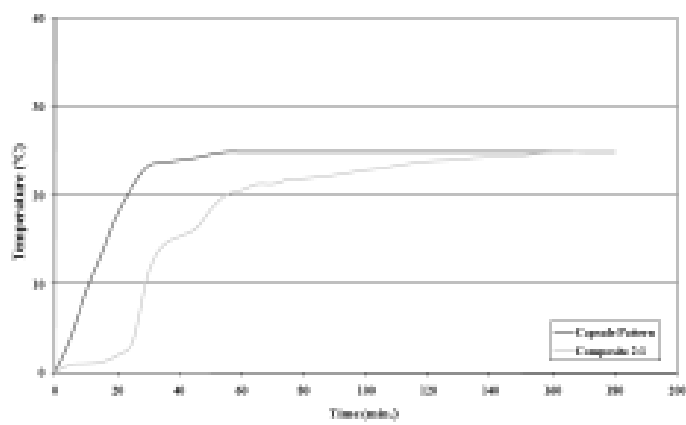

Figure 6. Resistance to the flow of heat - comparison pattern x composite $2: 1$.
It is observed in Figure 6, that after $30 \mathrm{~min}$, while the temperature of the capsule pattern increased of $0.1^{\circ} \mathrm{C}$ for $23.4^{\circ} \mathrm{C}$, therefore $23.3^{\circ} \mathrm{C}$. The isolated capsule with composite $2: 1$ passed of $0.2^{\circ} \mathrm{C}$ for $11.2^{\circ} \mathrm{C}$, that is, $11^{\circ} \mathrm{C}$ of increase; the difference among the two capsules was of $\Delta \mathrm{T}=12.8^{\circ} \mathrm{C}$.

After $45 \mathrm{~min}$, the temperature difference among the two capsules decreased to $\Delta \mathrm{T}=8.1^{\circ} \mathrm{C} ; 1: 00 \mathrm{~h}$ then, the difference was in $\Delta \mathrm{T}=4.4^{\circ} \mathrm{C}$. After $2: 00 \mathrm{~h}$, the difference was in $\Delta \mathrm{T}=1.1^{\circ} \mathrm{C}$. In the end of $180 \mathrm{~min}$ of measurements, the temperature difference between pattern and composite 2:1 became negligible.

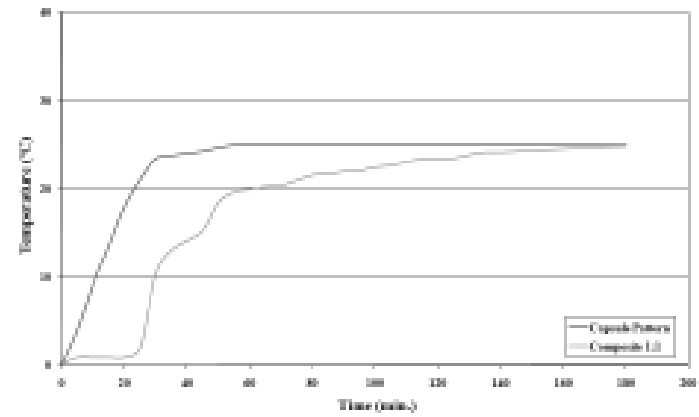

Figure 7. Resistance to the flow of heat - comparison pattern $x$ composite $1: 1$.

In Figure 7, the behavior of the pattern and of the composite 1:1. Observed that, after $30 \mathrm{~min}$ the temperature difference among the two was $\Delta \mathrm{T}=13.1^{\circ} \mathrm{C}$; after $45 \mathrm{~min}, \Delta \mathrm{T}=9.0^{\circ} \mathrm{C}$; after $1: 00$, the reduction was of $\Delta \mathrm{T}=5.0^{\circ} \mathrm{C}$ and after $2: 00 \mathrm{~h}$, $\Delta \mathrm{T}=1.6^{\circ} \mathrm{C}$. With $3: 00 \mathrm{~h}$ of experiment, the temperature difference among the two bodies was negligible $\left(0.1^{\circ} \mathrm{C}\right)$.

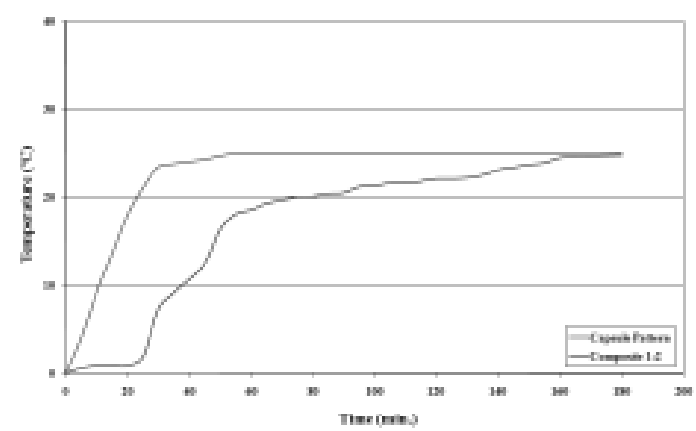

Figure 8. Resistance to the flow of heat - comparison pattern $\mathrm{x}$ composite 1:2.

In Figure 8, the behavior of the standard composite and of the composite 1:2. Observed that, after $30 \mathrm{~min}$ the temperature difference among the two was $\Delta \mathrm{T}=14.6^{\circ} \mathrm{C}$; after $45 \mathrm{~min}, \Delta \mathrm{T}=11.8^{\circ} \mathrm{C}$; after $1: 00$, the reduction was of $\Delta \mathrm{T}=6.4^{\circ} \mathrm{C}$ and after $2: 00$, $\Delta \mathrm{T}=2.9^{\circ} \mathrm{C}$. With $3: 00 \mathrm{~h}$ of experiment, the temperature difference among the two bodies was negligible $\left(0.2^{\circ} \mathrm{C}\right)$. 


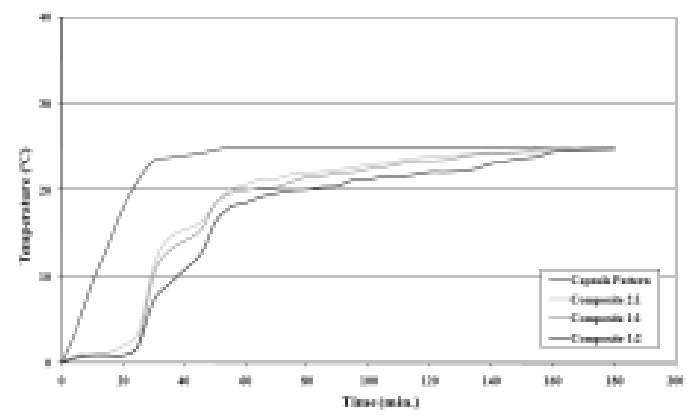

Figure 9. Resistance to the flow of heat - comparison.

The comparison among the composites can be observed in the figure 9 . The similarity of behavior is verified among the insulating ones. However the composite 1:2 came as the most appropriate for end of thermal isolation, in cold systems $\left(0^{\circ}\right)$, due to the largest thermal conservation.

\section{CONCLUSIONS}

- The geometric characteristics and structure they allow that scrapes of tire it is used for production of blankets, given your flexibility, lightness and resistance to temperatures of to $0^{\circ} \mathrm{C}$.

- Among the analyzed residues, it's suggested the use of the scrapes of tire as one of the most appropriate for production of the composite, because your properties revealed that the same satisfies to the minimum requirements for such an objective, as resistance to the temperature, lightness, flexibility besides having smaller improvement cost.

- The natural rubber (latex) can also be used together with you scrape them of tire in thermal applications to the limit of temperature of $0^{\circ} \mathrm{C}$, without damages to your structure.

- The composite can be used as insulating thermal until the limit of temperature of $0^{\circ} \mathrm{C}$ without risk of damages to your structures.

- Among the analyzed composites, the 1:2 came as the most appropriate for end of insulating thermal, in cold systems, due to the smallest thermal conductivity.

\section{ACKNOWLEDGEMENTS}

The authors acknowledge with gratitude the support of the PPGEM-UFRN; FEUP-UP; INEGI-UP and CAPES.

\section{REFERENCES}

ABNT., 1997, Resíduos Sólidos, ABNT/NBR 10004, Rio de Janeiro. (in Portuguese)
ASTM-C 177, 1982, Steady-state thermal transmission properties by means of the guarded hot plate.

Bertolo, S. A., 2008, Avaliação laboratorial de misturas asfáltica densas modificadas com borracha reciclada de pneus, São Carlos, Escola de Engenharia de São Carlos, Universidade de São Paulo. (in Portuguese)

Bovea, M. D., and Gallardo, A., 2006, The influence of impact assessment methods on materials selection for Eco-design, Materials and Design, Vol. 27, pp. $209-215$.

Callister, W. D. Jr., 1997, Materials science and engineering, 4. Ed, New York: Wiley.

Cao, W., 2007, Study on properties of recycled tire rubber modified asphalt mixtures using dry process, Construction and Building Materials, Vol. 21, pp. 1011-1015.

Fiori, J., 2009, Petrobrás tira óleo de pneu usado cooperando com o combate da dengue, Revista Limpeza Pública, Associação Brasileira de Limpeza Pública - ABPL. São Paulo.

Grippi, S., 2001, Lixo, reciclagem e sua história: guia para prefeituras brasileiras, Rio de Janeiro: Interciência. (in Portuguese)

Kreith, F., 2008, Princípios da transmissão de calor. 9th ed. São Paulo, Editora Edgard Blucher.

Larsen, M. B., Schultz, L., Glarborg, P., Jensen, L. S., Johansen, K. D., Frandsen, F., Henriksen, U., 2006, Devolatilization characteristics of large particles of tire rubber under combustion conditions, Fuel, Vol. 85, pp. $1335-1345$.

Leber, A. P., 2001, Overview of isoprene monomer and polyisoprene production processes, Chem Biol Interact, Vol. 1, No. 135-136, pp.169-173.

Mano, E. B., 2000, Polímeros como materiais de engenharia, São Paulo, Editora Edgard Blucher Ltda. (in Portuguese)

MINISTERIO DA SAÚDE - MS., 2009, http://www.saude.gov.br. Brasilia, (accessed in Dec 2009).

Santos A., 2005, Avaliação do comportamento do concreto com adição de borracha obtida a partir da reciclagem de pneus com aplicação em placas prémoldadas, M.Sc. Thesis, Maceió. (in Portuguese)

Received: June 07, 2009

Revised: July 07, 2009

Accepted: August 07, 2009 